\title{
Jameson on Jameson
}

POST-CONTEMPORARY

INTERVENTIONS

Series Editors:

Stanley Fish and Fredric Jameson 
Jameson 


\section{on Jameson}

CONVERSATIONS ON CULTURAL MARXISM

Edited by IAN BUCHANAN

DUKE UNIVERSITY PRESS

Durham \& London

2007 


\section{(C) 2007 DUKE UNIVERSITY PRESS}

All rights reserved

Printed in the United States of America

on acid-free paper $\infty$

Designed by Amy Ruth Buchanan

Typeset in Minion by G\&S Typesetters.

Library of Congress Cataloging-in-Publication Data appear on the last printed page of this book.

Every effort has been made to trace copyright holders and to obtain their permission for the use of copyright material. The editors would be pleased to be notified of corrections that should be incorporated in future editions of this book. Finally, the editors would like to give thanks to Tanya Buchanan who did an enormous amount of behind-the-scenes work to help realize this project. 
FOR MY STUDENTS 
